\title{
REVISITING KEYNES' INVESTMENT AND SAVING MODEL IN INDONESIA
}

Cheng-Wen Lee* ${ }^{*}$, Andrian Dolfriandra Huruta** iD , Ramdani Putri Setyaningrum*** iD, Gatot Sasongko**** id

DOI: $10.51558 / 2303-680 X .2020 .18 .2 .45$

\section{Abstract}

This study aims to analyze the Keynes investment and saving model in Indonesia from 1981 to 2018. The researchers use the econometric test from the Granger causality test to find the short-run causal relationship and the Vector Error Correction Model to reveal both the short-run and long-run effects in the model. The result of Granger causality test demonstrates that there is no short-run causal relationship between these two variables. In the short-run, the increase in saving affects the consumption loans more compared to the investment loans. Besides, increased consumption compared to saving has more influence in raising investment. However, the Vector Error Correction Model proves that saving negatively affects investment in the long-run. This model empirically supports the long-run Keynes' investment and saving model. Consequently, the Indonesian government needs to consider saving as a policy instrument to increase investment in the longrun.

Keywords: investment, saving, vector error correction model, Granger causality

JEL: B22, E2

\section{Introduction}

Indonesia has undergone numerous shocks that led to a sluggish economy. The first economic crisis took place in 1963 due to a centralized economic system and substantial political cost during the Old Order era (in the mid-1960s).

According to the Special Unit of Bank Indonesia Museum, the inflation rate in 1966 was too high (635\%), and the investment declined sharply (Bank Indonesia, 2020).

From 1982 to 1988, the economic condition deteriorated because of falling oil prices that caused a double deficit of its trade balance. Also, in 1997 Thailand decided to float its Baht currency with USD, which triggered simultaneous capital outflows from Asia. Lastly, the USA's 2008 financial crisis that led to Lehman Brothers' bankruptcy began the global financial crisis that caused an economic downfall in Indonesia (Ministry for Economic Affairs of Republic Indonesia, 2017).

Although experiencing numerous economic shocks, Indonesia managed to recover its economic conditions through several postcrisis policies, such as devaluing its Rupiah (IDR) currency and tax-saving to maintain the capital accumulation. From 1981 to 2018, Indonesia demonstrated improved investment and saving (IS) trends. Indonesia's IS level from 1981 to 2018 could be considered controllable, although the gross saving level decreased in 1982 when the world oil price fell sharply. To cope with the declining oil price, the Indonesian government issued numerous policies such as reducing government expenditures, rescheduling and canceling several projects, devaluing IDR in April 1983, and reforming its tax, custom, and banking systems through the policy package on June 1 , 1983. The monetary crisis from 1997 to 1998 also changed the macroeconomic policies and, eventually, IS levels in Indonesia (World Bank,

* Department of International Business, Chung Yuan Christian University, Taiwan,
chengwen@cycu.edu.tw
PhD Program in Business, Chung Yuan Christian University, Taiwan \& Faculty of Economics and
Business, Satya Wacana Christian University, Indonesia, g10804610@cycu.edu.tw
F** Faculty of Economics and Business, Satya Wacana Christian University, Indonesia,
$222016001 @ s t u d e n t . u k s w . e d u$
**** Faculty of Economics and Business, Satya Wacana Christian University, Indonesia,
gatot.sasongko@staff.uksw.edu


2019a; 2019d). Consequently, during the observation period, the Indonesian government took numerous steps to restabilize the IS variables to finance its development programs.

Prior studies by Yamori (1995), Tsoukis and Alyousha (2001), Tehranchian and Behravesh (2011), Jangili (2011), Mensah (2012), Jošić and Jošić (2012), Kumar, Webber, and Fargher (2012), Hundie (2014), Rahman and Hossain (2015), Al-Afeef and Al-Qudah (2015), Itoe and Atangana (2015), Abusomwan and Ezebuihe (2017), Aka (2017), Yadav, Goyari and Mishra (2018), Alrasheedy and Alaidarous (2018) empirically confirm the IS model by arguing that investment increases because of increased saving. However, several studies fail to uphold the IS model to argue that these two variables' positive correlation indicates that investment increases saving, not vice versa (Onafowara, Owoye, \& Huart, 2011; Ngouhouo \& Mouchili, 2014).

Meanwhile, some studies even show that there is no relationship between investment and saving in the studied countries (Esso \& Keho, 2010; Gebeyehu, 2011; Sakalya, 2012; Mehrara \& Musai, 2014; Ogbokor \& Musilika, 2014; Aka, 2017; Mansoor, Sultana \& Saeed, 2018). Further, several studies have tried to explain the positive two-way correlation between these two variables and suggest that the increased saving increases investment and vice versa (Mngqibisa, 2014; Irandoust, 2017).

There has been an ongoing debate among academics on the correlation between investment and saving. Keynes' theory argues that increases in the public and government income will result in increased saving that will be implemented to the country's investment activities. In this respect, an investment can be an endogenous factor due to the accumulation process of saving and an exogenous variable that potentially affects saving. Keynes assumes that the government intervention by increasing investment will enhance the output growth and reduce unemployment.

Considering the importance of IS level, this study analyzes the causality between saving and investment in Indonesia using 37 years of observation (1981-2018). Thus, this study uses the Granger causality and Vector Error
Correction Model (VECM) to investigate both the short-run and long-run causal relationship between these two variables in Indonesia.

\section{Literature review}

The IS curve in the Aggregate Demand theory explains the relationship between investment and saving. The IS curve term in the Aggregate Demand Theory identifies that the expected investment equals the expected saving. The following equation describes the relationship between these two variables (Mankiw, 2016).

$$
\mathrm{I}=[y-t-c]+(t-g)
$$

Based on Equation 1, a symbol I refer to as an investment, $y$ refers to income that will be deducted by $\mathrm{t}(\operatorname{tax})$ and c (consumption). At the same time, $g$ refers to the government expenditures. The left side of Equation 1 is the expected investment, while the right is the expected saving, where $\mathrm{y}-\mathrm{t}-\mathrm{c}$ is the household saving. If $t$ increases, the consumption will decrease. The government surplus $(\mathrm{t}-\mathrm{g})$ is the government saving. Public and private saving are components of the national income.

Equation 1 also suggests that the inflows to the financial market (the public and private saving) must equal the outflows from the financial market (investment). Both the public and private saving are the components of national income and result in Equation 2 and Equation 3.

$$
\begin{gathered}
I=Y-C-G \\
I=S
\end{gathered}
$$

Mankiw (2016) explains the relationship between the interest rate and investment in the IS curve. The interest rate likely affects investment and eventually saves because the interest rate explains the cost for borrowers to finance their investment projects. Consequently, increased interest rates will reduce planned investment. It can then be argued that saving is an economic variable that affects investment in the IS curve and not vice versa.

Furthermore, there has been extensive literature on the IS. For example, Gebeyehu 
(2011) found that saving did not affect investment, and investment did not affect Ethiopia's saving because it depended on debt, foreign aid, and FDI for its investment. A similar study by Aka (2017) in Ghana showed no causal relationship between these two variables because Ghana experienced relatively unstable political conditions since 1966. On the other hand, Esso and Keho (2010) empirically demonstrated that investment was positively correlated with domestic saving only in three countries (Benin, Côte d'Ivoire, and Niger) out of seven member countries (Benin, Burkina Faso, Côte d'Ivoire, Mali, Niger, Senegal, and Togo). In four other states, investment is not related to the domestic saving. The findings indicated that most investments in these countries were not financed by domestic saving but by foreign saving. Thus, it was understandable that these four countries (Burkina Faso, Mali, Senegal, and Togo) launched policies that focused on incentivizing investment and reducing capital outflows. However, Benin, Côte d'Ivoire, and Niger also experienced imperfect capital flow, mainly because of political risk in Côte d'Ivoire, human resource quality in Niger, and infrastructure quality in Benin.

Sakalya (2012) showed the informal capital market's most economic activities and novel financial innovation, such as GDRs, ADRs, FCCBs, and infrastructure bonds. Together with the lower interest rates relative to other countries, these factors attracted the Indian private and public sectors. Consequently, a significant portion of domestic saving shifted to the unorganized sector, and eventually, the official saving was not related to investment. Meanwhile, Mehrara and Musai (2014) found that saving had no relation to investment and attributed their findings to the high capital mobility level in 40 Asian countries from 1970 to 2010 .

Another study by Ogbokor and Musilika (2014) observed no causality between investment and saving in Namibia because it experienced a high capital outflow level. No cointegration led to relatively high capital mobility and capital outflow and caused domestic investment to rely more on foreign saving than the domestic saving. In this respect, Namibia's gross domestic savings only played a passive role in financing the capital formation. This country depended on their foreign financing sources to finance their domestic investment. Consequently, the local investment had to be funded by the international capital flow. The current account deficit in the balance of payments also explained the lack of causality between these two variables.

Similarly, Mansoor, Sultana, and Saeed (2018) used the data panel cointegration test to investigate the long-run relationship between investment and saving in the G-7 countries from 1970 to 2015 . The results indicated that the IS did not exhibit long-run relationships in these countries. It means that the lack of longrun equilibrium between investment and saving in these countries was due to the decreased saving.

While several studies do not find the causal relationship between investment and saving, other studies demonstrate that investment affects saving. For example, Ngouhouo and Mouchili (2014) revealed the causal relationship between investment and saving in Cameroon because of the Structural Adjustment Program. This program provided the IMF and the World Bank aid to countries experiencing an economic crisis. It stipulated these countries implement specific policies to fund extensive and impactful construction projects that created many employment opportunities and eventually increased the public income. In this respect, Cameroon could be classified into the HIPC (Highly Indebted Poor Countries) initiative - a group of onceheavily indebted and low-income countries but currently exhibiting much better economic performance.

Similarly, Onafowara, Owoye, and Huart (2011) showed a cointegrated relationship between investment and saving in six out of eight European Union (EU) countries. They also empirically showed the long-term causality from investment to saving in Denmark, Germany, and Luxembourg; a one-way causality from saving to investment in the Netherlands and the UK; a two-way causality in Belgium; and neutrality in France and Italy. These countries in which investment affected saving would be better off by not reducing the public expenditures that positively impacted 
the private investment. It is not appropriate to raise taxes when saving affects investment because it negatively affects private saving and, consequently, aggregate saving.

Previous studies have found the causality from saving to investment. For example, Yadav, Goyari, and Mishra (2018) demonstrated that domestic saving played a significant role in India's capital formation. Similarly, Aka (2017) described the causal relationship from saving to investment in Ivory Coast historically and found that the country enjoyed political stability before the coup d'etat (December 1999) and war (September 2002). The results suggested a peaceful environment could potentially attract the foreign investment in Sub-Saharan Africa.

Jošić and Jošić (2012) empirically observed the cointegrated relationship in the IS in Croatia. The findings indicated the strong long-term dependency on the domestic investment in domestic saving. Next, using the Impulse Response Function and Forecast Error Variance Decomposition, Hundie (2014) found a causality from saving to investment. He suggested that sufficient loan access such as a stimulated domestic investment and sufficient gross domestic saving would increase the IS. Further, Tehranchian and Behravesh (2011) demonstrated that the Iranian economy exhibited a considerable fluctuation in economic growth and gross domestic investment, especially in the last half of the century. The instability caused saving to fail to finance all investment needs. The Granger causality test further confirmed their results, which indicated the one-way causal relationship from saving to investment. By using the Granger causality and Cointegration, Rahman and Hossain (2015) proved a causal relationship from saving to investment in Bangladesh. However, the domestic saving in Bangladesh was from households whose saving had a higher proportion than the foreign saving. In this respect, relying on the foreign saving would likely deter sustainable economic growth in Bangladesh.

Kumar, Webber, and Fargher (2012) also found the causality from saving to investment. They attributed their findings to the increased capital mobility in Australia due to the open economy with stable ratios between the current balance account to Gross Domestic Product (GDP). In Germany, Tsoukis and Alyousha (2001) showed a one-way causality from investment to saving during the entire post-war period. After the war, the continuously increasing current balance improved the German economy and enabled the accumulated saving on facilitating investment. In Cameroon, Itoe and Atangana (2015) revealed a positive correlation between investment and saving. However, the Vector Auto Regression suggested that saving did not significantly affect investment. Understandably, the lack of entrepreneurship caused many projects to be ineligible for the bank loans.

According to Jangili (2011), although the Indian economy accepted the foreign investment, their domestic saving was still the primary growth factor. Besides, the local firms did not absorb novel technologies from foreign investment and utilized them to initiate profitable innovation projects. In Saudi Arabia, Alrasheedy and Alaidarous (2018) empirically found a one-way causality from the foreign saving to the foreign investment. Meanwhile, Abusomwan and Ezebuihe (2017) underscored the importance of increased investment during Nigeria's economic downturn. The government understandably needed to push the aggregate demand to increase the total outputs through the contractive fiscal and monetary policies. Such policies helped the government overcoming the demand-pull inflation pressure.

Consequently, the domestic saving would increase, and the gross capital formulation would be sustainable. In Jordan, Al-Afeef and Al-Qudah (2015) highlighted that the country did not achieve the necessary saving level for the capital accumulation because of several obstacles such as security instability that slowed down the economic performance. Consequently, the income level was so low that it negatively affected capital formation.

Mensah (2012) showed that the firms' saving (retained earnings), the central government saving, low consumption, and high tax revenue were the main factors that increased China's saving. Meanwhile, investment funded by 
domestic saving and foreign direct investment only played a relatively minor role. Thus, the firms' investment expenditure, fiscal federalism, and economic decentralization were understandably the main reasons for China's high investment level. Kaya (2010) also indicated a robust long-run relationship between the total investment and the total saving in Turkey. However, at the same time, there was no significant long-run relationship between private investment and private saving.

These two contradictory results were likely due to the payment target equilibrium and solvability constraints. In this respect, the government's ability to repay all its debts by using all of its assets was less than the target. Consequently, the country underwent a deficit and could not finance investment.

Besides the one-way causality and absence of causality, Mngqibisa (2014) empirically demonstrated a two-way causality between investment and saving. The financial sector development was considered crucial to start an investment cycle and increase saving (financial investment).

Thus, sustaining the sequence was necessary to push South Africa to a higher developmental stage level. Then, Irandoust (2017) also explained that the change in the saving level also changed the investment level and vice versa. Consequently, the foreign capital demand aimed to fund the investment projects in Russia, Estonia, Latvia, Lithuania, Belarus, and Ukraine.

\section{Research methodology}

This study used the time-series Indonesian data from 1981 to 2018 from the World Bank. The researchers selected this period to generate a comprehensive perspective of Indonesia's financial crisis in 1998 and the global financial crisis from 2007 to 2008 .

The IS model analyzes the relationship between investment and saving (Mankiw, 2016).

Table 1 below displays the definition and measurement of each variable.
Table 1. Variable measurement

\begin{tabular}{|c|c|c|}
\hline Variable & Operational definition & Indicator \\
\hline Investment & $\begin{array}{c}\text { Investment of money or } \\
\text { capital in physical or } \\
\text { financial forms to generate } \\
\text { profits }\end{array}$ & $\begin{array}{c}\text { Formation of } \\
\text { Gross } \\
\text { Domestic } \\
\text { Fixed Capital }\end{array}$ \\
\hline Saving & $\begin{array}{c}\text { The portion of income that } \\
\text { is not included in } \\
\text { consumption and saving for } \\
\text { future purposes }\end{array}$ & Gross saving \\
\hline
\end{tabular}

Source: Central Bureau of Statistics (2015)

The stationary test confirms the time series data movement' consistency to check whether the data shows a tendency to approach its mean value (stationary) and have a low variance (Hill, Griffiths, \& Lim, 2018). The following are the equations in the stationary test.

$$
\begin{aligned}
& Y_{t}=\alpha+\gamma y_{t-1}+\lambda_{t}+v_{t} \\
& X_{t}=\alpha+\gamma x_{t-1}+\lambda_{t}+v_{t}
\end{aligned}
$$

The Augmented Dickey-Fuller (ADF) test includes a constant and a trend in the test equation. The normality, heteroskedasticity, and autocorrelation test ensures that the model exhibits BLUE components (Johnson \& Wichern, 2007). Afterward, the researchers determined the optimal length of lag to investigate the number of lags used in the estimation and whether the model fits the actual data. The optimal lag can be determined by observing the smallest Akaike Information Criterion (AIC) value (Hill, Griffiths, \& Lim, 2018).

After determining the lag's optimal length, the Granger causality test is done using the optimal lag. The model illustrates the relationship between the variables explained by the Granger causality test (Granger, 1969).

$$
\begin{aligned}
& X_{t}=\alpha_{2} \sum_{t=1}^{m} c_{i} X_{t-i}+\sum_{j=1}^{n} d_{j} Y_{t-j}+v_{t} \\
& Y_{t}=\alpha_{1} \sum_{t=1}^{r} a_{i} Y_{t-i}+\sum_{j=1}^{s} b_{j} X_{t-j}+\mu_{t}
\end{aligned}
$$

In Equation 6 and Equation 7, $X_{\mathrm{t}}$ refers to saving, and $Y_{t}$ relates to investment. Meanwhile, $\mu_{\mathrm{t}}$ and $v_{\mathrm{t}}$ are error terms assumed not to contain serial correlation, and lagged time $\mathrm{m}=\mathrm{n}=\mathrm{r}=\mathrm{s}$.

Afterward, the cointegration test examines the long-run relationship between the variables, as illustrated by Equation 8 . 


$$
\Delta \hat{\mu}=\rho \hat{\mu}_{t-1}+\sum_{1}^{\rho} \alpha_{i} \Delta \hat{\mu}_{t-1}+e_{t}
$$

After detecting the long-run relationship between the variables, the researchers run the VECM test to differentiate the long-run and short-run components in the data formation process. The following Equation 9 illustrates the VECM model:

$$
\Delta Y_{t}=\mu_{0 x}+\mu_{1 x^{t}}+\Pi_{x} y_{t-1}+\sum_{i=1}^{k-1} \Gamma_{i x} \Delta y_{t-i}
$$

Where:

$Y_{t}$ is an analyzed variable vector

$\mu_{0 x}$ is an intercept vector

$\mu_{1 x}$ is a regression coefficient vector

$t$ is a time trend

$\Pi_{x}$ is $\alpha x \beta^{\prime} \alpha x \beta^{\prime}$ where $\beta^{\prime} \beta^{\prime}$ contains the

cointegration equation

$y_{t-1}$ is an in - level variable

$\Gamma_{i x}$ is a regression coefficient matrix

$k-1$ is the VECM order

$e_{t}$ is an error term.

\section{Results}

The model estimation ensures all research variables are stationary at the same degree and qualified for the Granger causality and VECM test. Table 2 presents the results of stationary test with the ADF.

Table 2. The stationary test

\begin{tabular}{|c|c|c|c|}
\hline Variable & $A D F$ & Critical Value 5\% & Probability \\
\hline Saving & -2.7044 & -2.9434 & 0.0829 \\
\hline Investment & -1.6197 & -2.9458 & 0.4625 \\
\hline * D(Saving) $^{-}-7.6181$ & -2.9540 & $0.0000^{* *}$ \\
\hline${ }^{*} \mathrm{D}$ (Investment) & -8.1847 & -2.9484 & $0.0000^{* *}$ \\
\hline
\end{tabular}

Note: *D indicates the first-order difference.

$* *$ significant at $\mathrm{p}<0.001$.

Source: Authors' calculation

Table 2. indicates the IS is stationary at the first integration degree or I(1), which can be seen from the ADF value of the investment variable of -8.184659 that is greater than the $99 \%$ confidence level $(\tau=-2.948404)$ and the probability value of $0.0000(p<0.001)$. Meanwhile, the saving variable has an ADF value of -7.618109 that is greater than the $99 \%$ confidence level $(\tau=-2.954021)$ and the probability value of $0.0000(p<0.001)$. Further, Figure 1 below exhibits the results of the normality assumption test. It shows the probability value of $0.598233(p>0.05)$, suggesting that the residual is normally distributed. Next, Table 3 displays the results of the autocorrelation test.
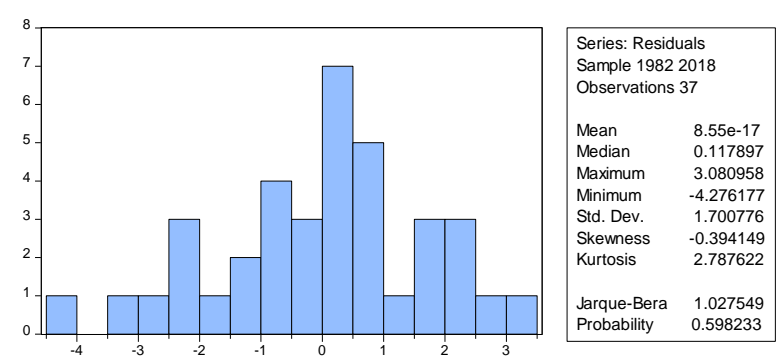

Figure 1. Normality test

Source: Authors' calculation

Table 3 presents the Chi-Square probability value of $0.1925(p>0.05)$, indicating the absence of autocorrelation. Further, Table 4 shows the results of the heteroskedasticity.

Table 3. The autocorrelation test

\begin{tabular}{|c|c|c|c|}
\hline F-statistic & 1.6131 & Prob.F (2.34) & 0.2146 \\
\hline Obs*R-squared & 3.2950 & Prob. Chi-Square (2) & 0.1925 \\
\hline
\end{tabular}

Source: Authors' calculation

Table 4 suggests the model is free from heteroskedasticity. Specifically, the Chi-Square probability value is 0.1917 ( $p>0.05$ ). Next, Table 5 presents the Vector Autoregression test to analyze the presence of a causal relationship.

Table 4. The heteroskedastisity test

\begin{tabular}{|c|c|c|c|}
\hline F-statistic & 1.6906 & Prob.F (1.35) & 0.2020 \\
\hline Obs*R-squared & 1.7049 & $\begin{array}{c}\text { Prob. Chi-Square } \\
(1)\end{array}$ & 0.1917 \\
\hline $\begin{array}{c}\text { Scaled explained } \\
\text { SS }\end{array}$ & 1.3636 & $\begin{array}{c}\text { Prob. Chi-Square } \\
\text { (1) }\end{array}$ & 0.2429 \\
\hline
\end{tabular}

Source: Authors' calculation

Table 5 indicates the investment level as the dependent variable is not significantly affected by the two variables at lag 1 . Conversely, the IS variables do not considerably affect saving as the dependent variable at lag 1.

The results imply that the IS variables do not significantly influence each other because of the small t-values.

The following equations illustrate the results: 


$$
\begin{aligned}
\mathrm{D}(\text { Investment }) & \\
& =0.186087296938 \\
& +0.286085825424 \\
& * \mathrm{D}(\text { Investment })(-1) \\
& -0.00753423718428 \\
& * \mathrm{D}(\text { Saving })(-1) \\
& \\
\mathrm{D}(\text { Saving })= & 0.502732290908 \\
& +0.00555644008033 \\
& * \mathrm{D}(\text { Investment })(-1) \\
& -0.194864122586 \\
& * \mathrm{D}(\text { Saving })(-1)
\end{aligned}
$$

Table 5. The vector autoregression test

\begin{tabular}{|l|c|c|c|c|}
\hline \multirow{2}{*}{\multicolumn{1}{|c|}{ Statistics }} & \multicolumn{2}{|c|}{ D(Investment) } & \multicolumn{2}{c|}{$D$ (Saving) } \\
\cline { 2 - 5 } & Coefficient & $t$-stat & Coefficient & $t$-stat \\
\hline D(Investment)(-1) & 0.2861 & 1.6413 & 0.0056 & 0.0147 \\
\hline D(Saving)(-1) & -0.0075 & -0.0936 & -0.1949 & -1.1169 \\
\hline $\mathrm{C}$ & 0.1861 & 0.6190 & 0.5027 & 0.7718 \\
\hline $\mathrm{R}^{2}$ & 0.0799 & & 0.0395 & \\
\hline F-statistic & 1.4328 & & 0.6793 & \\
\hline Log-likelihood & -70.236 & & -98.0714 & \\
\hline Akaike AIC & 4.0687 & & 5.6151 & \\
\hline Schwarz SC & 4.2006 & & 5.7470 & \\
\hline
\end{tabular}

\section{Source: Authors' Calculation}

Next, the lag length followed after the VAR test aims to analyze the optimal lag to use in the subsequent analysis. Table 6 demonstrates the optimal lag to determine the effect of a variable on the lagged variable. Another endogenous variable is lag 1 , as indicated by the AIC value at lag 1 , which is less than the amount in different lags (9.283828). Thus, lag 1 is used in the Granger causality and VECM test to determine the IS level' shocks.

Table 6. The lag length test

\begin{tabular}{|c|c|c|c|c|c||c|}
\hline Lag & LogL & LR & $F P E$ & AIC & $S C$ & $H Q$ \\
\hline 0 & -147.873 & NA & 40.0982 & 9.3670 & $9.4587^{*}$ & 9.3974 \\
\hline 1 & -142.541 & $9.663291^{*}$ & $36.936^{*}$ & $9.2838^{*}$ & 9.5586 & $9.3749^{*}$ \\
\hline 2 & -139.368 & 5.354947 & 39.052 & 9.3355 & 9.7935 & 9.4873 \\
\hline 3 & -135.870 & 5.465313 & 40.670 & 9.3669 & 10.008 & 9.5794 \\
\hline 4 & -134.426 & 2.075961 & 48.522 & 9.5266 & 10.3511 & 9.7999 \\
\hline 5 & -133.348 & 1.414895 & 59.851 & 9.7092 & 10.7169 & 10.0432 \\
\hline
\end{tabular}

Source: Authors' calculation

Table 7 shows the null hypothesis that predicting that saving does not cause investment is empirically supported. The decision is based on the probabilistic value of 0.9260, which is higher than the 0.05 significance value. Similarly, investment also does not affect saving $(0.9883>0.05)$.
Table 7. The Granger Causality Test

\begin{tabular}{|c|c|c|c|}
\hline Null Hypothesis: & Obs. & $\begin{array}{c}F- \\
\text { Statistic }\end{array}$ & Prob. \\
\hline $\begin{array}{c}\text { D(Saving) does not cause } \\
\text { D(Investment) }\end{array}$ & 36 & 0.0088 & 0.9260 \\
\hline $\begin{array}{c}\text { D(Investment) does not cause } \\
\text { D(Saving) }\end{array}$ & & 0.0002 & 0.9883 \\
\hline
\end{tabular}

Source: Authors' Calculation

Moreover, Table 8 below presents the results of the Johansen Cointegration test. Based on Table 8, the statistical values indicate a cointegration and a stationary linear relationship between investment and saving. Due to the model being qualified for the cointegration condition, the VECM is run.

Table 8. The Johansen Cointegration Test

\begin{tabular}{|c|c|c|c|c|}
\hline $\begin{array}{c}\text { Hypothesized } \\
\text { No.of CE(s) }\end{array}$ & $\begin{array}{c}\text { Eigen } \\
\text { value }\end{array}$ & $\begin{array}{c}\text { Critical } \\
\text { value (5\%) }\end{array}$ & $\begin{array}{c}\text { Max- } \\
\text { Eigen }\end{array}$ & $\begin{array}{c}\text { Critical } \\
\text { value (5\%) }\end{array}$ \\
\hline & 0.576 & & 30.06 & \\
None* $^{*}$ & 439 & 15.49471 & 705 & 14.26460 \\
\hline & 0.323 & & 13.65 & \\
At most 1* & 095 & 3.841466 & 785 & 3.841466 \\
\hline
\end{tabular}

Source: Authors' calculation

Further, the VECM test for the IS is run by analyzing the factors that affect them in both the short and long-run. Table 9 below displays the results of the VECM.

\section{Table 9. The VECM Estimation Results}

\begin{tabular}{|c|c|c|}
\hline \multicolumn{3}{|c|}{ Long-Run } \\
\hline Variable & Coefficient & t-statistic \\
\hline $\mathrm{D}($ Investment)(-1) & 1 & \\
\hline $\mathrm{D}($ Saving)(-1) & -2.730409 & $*[-6.80911]$ \\
\hline \multicolumn{3}{|c|}{ Short-Run } \\
\hline Variable & Coefficient & t-statistic \\
\hline CointEq1 & -0.005 & {$[-0.08755]$} \\
\hline $\mathrm{D}(\mathrm{D}$ (Investment)(-1)) & -0.330988 & {$[-1.86477]$} \\
\hline $\mathrm{D}(\mathrm{D}($ Saving)(-1))) & -0.002723 & {$[-0.02770]$} \\
\hline
\end{tabular}

Note: *significant at the level of 0.05

Source: Authors' Calculation

The long-run equation results in the VECM estimation in Table 9 above indicate that investment level movement is significantly affected by the saving level change. Meanwhile, the saving levels negatively affect the investment level by -2.730409 . The results confirm the theory. Notably, a 1\% increase in the saving level will negatively respond to a $2.73 \%$ decrease in investment. Conversely, a $1 \%$ decrease in the saving level will increase the investment level by $2.73 \%$.

The VECM estimation results for saving show that in the short-run, the error correction value from the short-run to the long-run is -0.005 . 
The coefficient of the error correction term indicates how quickly the research variable moved toward the equilibrium line. The ratio should be significant and have a negative correlation. The high significance of error correction suggested a stable long-run relationship (Banerjee, Dolado, and Mestre, 1998). However, the results show an insignificant coefficient. The findings implied no long-lasting long-run relationship, but the ties fluctuated, causing the long-run relationship to be not constant.

In the short-run analysis, a $1 \%$ increase of investment in the previous year has an insignificantly negative effect on the decrease of the current savings by $0.33 \%$, and vice versa. Meanwhile, a $1 \%$ increase in saving in the previous year has an insignificantly negative effect on the decrease of the current investment by $0.002 \%$, and vice versa.

\section{Discussion}

The results of the Granger causality and VECM test were empirically supported by prior researches such as Aka (2017), Esso and Keho (2010), Gebeyehu (2011), Mansoor, Sultana, and Saeed (2018), Mehrara and Musai (2014), Ogbokor and Musilika (2014), and Sakalya (2012) that found there was no short-run causality between investment and saving. However, these two IS variables showed a longrun equilibrium. While the IS affected each other in the long-run, the short-run effects should also be paid. Several factors had shortrun impact on saving. First, the Keynes IS model explains that the interest rate will affect the fund supply and demand in the goods market. Second, Indonesia's deficit current balance condition potentially triggered the absence of causality between investment and saving. In this condition, the government could not finance their investment projects unless relying on the foreign capital flow. Third, the consumption behavior and lifestyle would arguably trigger the consumption loans but not the investment ones. In this respect, the consumption loans likely reduced saving in Indonesia. Figure 2 below displays the dynamics of consumption loans in Indonesia.

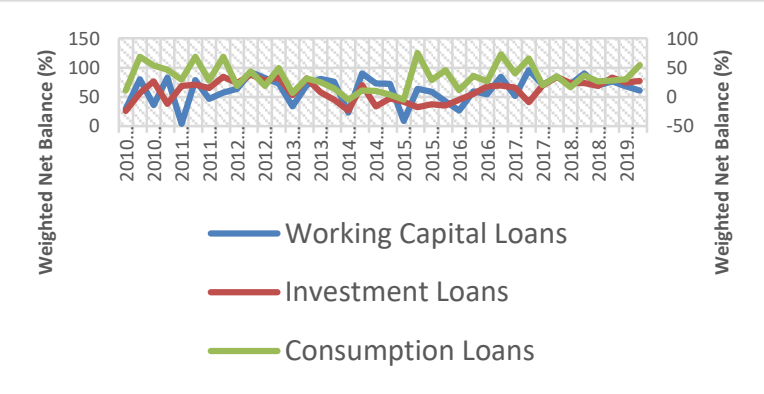

Figure 2. Demand for New Loans from 2010 to 2019

Source: Bank of Indonesia (2019b)

Figure 2 shows in quarter 2 of 2015, the consumption loans exceeded investment loans and the working capital loans. All types of loans also fluctuated continuously. The figure also shows that in 2019, the consumption loans were almost equal to the working capital loans. The life cycle hypothesis explains that the younger population showed a greater tendency to consume and borrowed money for various purposes. They would pay the loans because they were employed and would get income in the future. In other words, they used saving that was supposed to be for their older period (Modigliani, 1986). Consumption forced them to apply for additional consumption loans. It also assumed that when the baby boomers reached their pension age, the younger generation became the taxpayers and would support their parents. As such, they had to work longer with less real wages (Dolphin, 2012). Next, the banks also targeted their loans to the productive-age population, especially the younger ones. New workers would arguably experience increased living expenses due to the high inflation rate, stagnant wage, and obligation to support families financially. Most workers would also leave their houses and purchase or rent a house/room after having jobs. These financial burdens made them perfect for a loan target (Jappelli \& Modigliani, 1998). Besides, the household consumption level also tended to increase. It can be seen in Figure 3 below. 


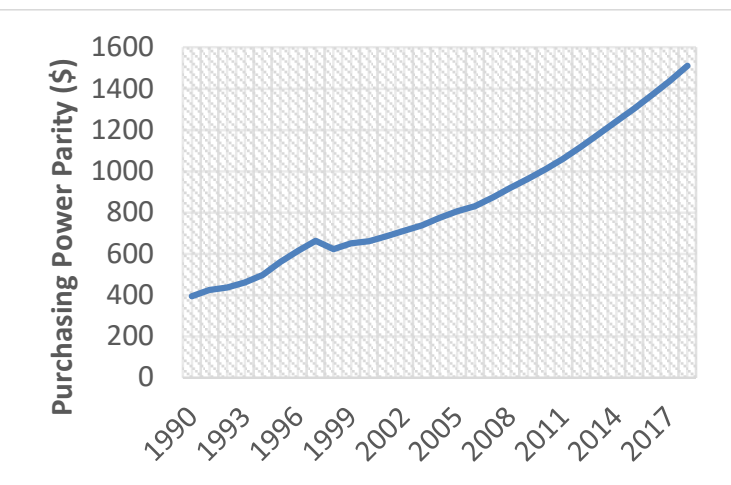

Figure 3. Indonesian Household Consumption Level

Source: World Bank (2019c)

Figure 3 describes the Indonesian household consumption expenditure continued to increase during the observation period. The new workers would arguably receive the minimum wages. Thus, they tended to use their wages to satisfy their primary needs, i.e., mostly for consumption. They would likely apply for the loan if they received wages that could not afford their consumption expenditure (Dolphin, 2012). Consequently, they had to repay their debts during the loan periods. Having to satisfy their consumption needs and repaying their debts simultaneously left them unable to save (Modigliani, 1986).

The Keynesian approach could be used to analyze output fluctuations and price levels (Mankiw, 2016). On the national income, Keynes explained that the amount of consumption, investment, government spending, and net exports affect a country's national income. Then, the price system plays an essential role in changing the national income components, especially consumption.

The price level in each commodity influences how much consumption will be spent (Organisation for Economic Cooperation and Development, 2011; Niu, Chu, \& Ma, 2016). It can be seen in Figure 4.

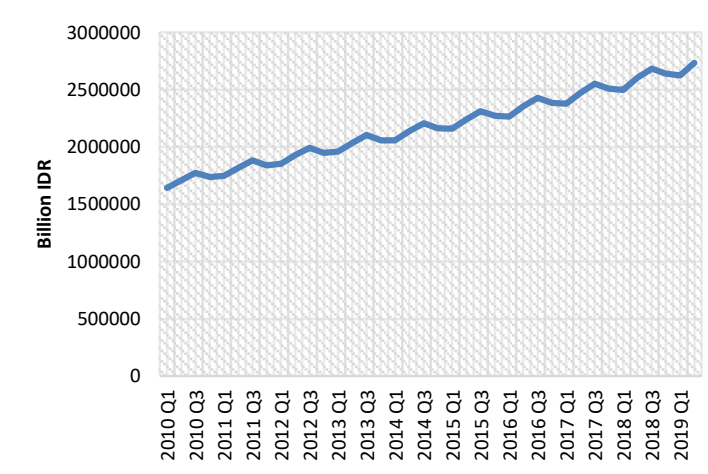

Figure 4. GDP at Constant Prices Based on Expenditures

Source: Central Bureau of Statistics (2019, 2016)

Figure 4 shows the national income by expenditure continued to increase. This phenomenon is in line with consumption, which is always growing in Indonesia. A person's ability to meet their consumption needs could be indicated by estimating the purchasing power parity (Organisation for Economic Cooperation and Development, 2011; Niu, Chu, \& Ma, 2016). The value of purchasing power parity in Indonesia continued to increase, which was the impact of an increase in the society's real income. The improvement in human resources and infrastructure completeness also increased the purchasing power parity (World Bank, 2019d).

Furthermore, the consumption would encourage investment growth and increase GDP (Gebeyehu, 2011; Kira, 2013; Mngqibisa, 2014; Al-Afeef \& Al-Qudah, 2015). Eventually, a high level of consumption loans left saving insufficient to fund the public investment projects (Yamori, 1995; Tsoukis \& Alyousha, 2001; Rahman \& Hossain, 2015).

Figure 5 below presents the relationship between the worker's income and domestic loans. 


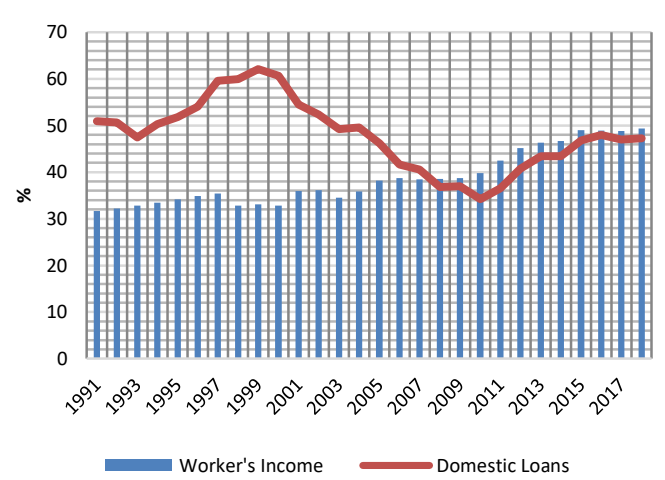

Figure 5. Indonesian Workers' Income and Domestic Loans

Source: World Bank (2019e, 2019b)

Figure 5 illustrates the Indonesian population who depended on loans from 1991 to 2007. During that period, the bank loan composition was dominated mainly by loans to productive sectors, such as agriculture, industry, trade, etc. Most debtors were farmers, entrepreneurs, or traders. However, the loan-level improved afterward until 2018 because of numerous professions with higher wages. It indicated that the workers' consumption loans began to dominate the loan composition. In this respect, the loan consumption caused the IS to increase insignificantly (Esso \& Keho, 2010; Hundie, 2014; Al-Afeef \& Al-Qudah, 2015; Alrasheedy \& Alaidarous, 2018). Consequently, the current account balance could not support the public investment project growth (Park \& Shin, 2009; Kumar, Webber \& Fargher, 2012; Mngqibisa, 2014; Mansoor, Sultana \& Saeed, 2018). Figure 6 describes the equilibrium of the current account balance.

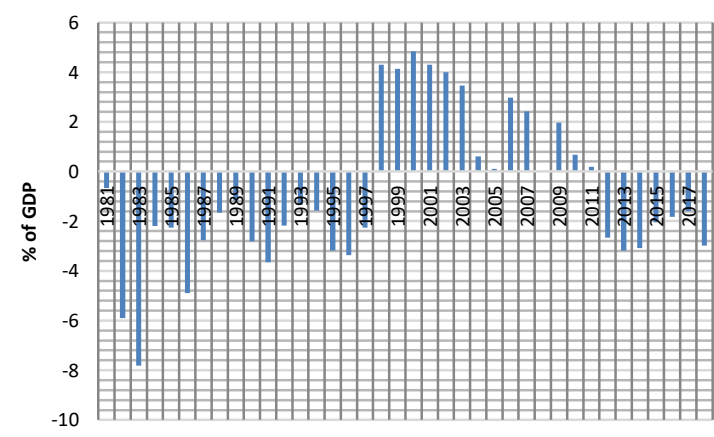

Figure 6. Indonesian Equilibrium of the Current Account Balance

Source: World Bank (2019a)
Figure 6 indicates financing investment could not solely rely on saving because of the current account deficit. In this respect, the foreign loans likely financed investment (Tsoukis \& Alyousha, 2001; Park \& Shin, 2009; Esso \& Keho, 2010; Kaya, 2010; Mehrara \& Musai, 2014; Ogbokor \& Musilika, 2014; Itoe \& Atangana, 2015). The deficit account balance required a greater certainty in terms of whether liabilities were free from default risk through future trade balance surplus. The future trade balance surplus should not reduce the consumption and run the economy by relying on the capital inflow to increase the future outputs. The government could achieve such objectives by increasing the investment level to repay the creditors. Thus, the economic capacity to produce tradable goods and services must increase (Jangili, 2011; Tehranchian \& Behravesh, 2011; Klemm, 2013; Mngqibisa, 2014; Rahman \& Hossain, 2015). Besides, a high amount of sovereign debt likely indicated that the foreign fund, not saving, financed investment (Jangili, 2011; Ngouhouo \& Mouchili, 2014; Irandoust, 2017). It can be seen in Figure 7 below.

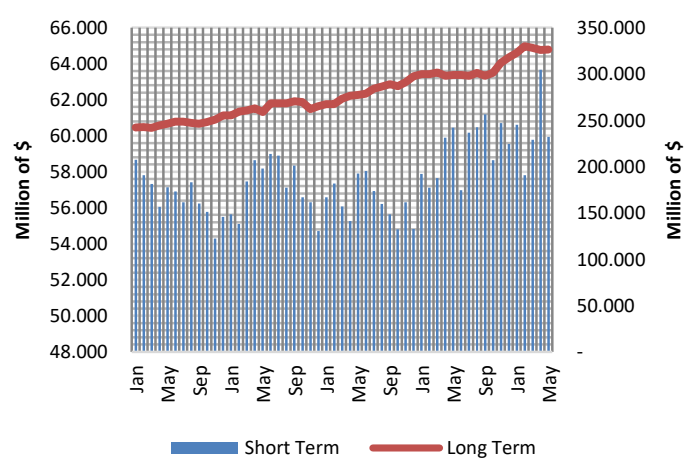

Figure 7. The Amount of Sovereign Debt (2015 to 2019)

Source: Bank of Indonesia (2019a)

Until March 2019, the Indonesian short-term debt was 59,933 million dollars, while the longterm debt was 326,202 million dollars. The foreign financing of investment projects caused Indonesia to repay the current deficit account's debts and interest (Gebeyehu, 2011; Abusomwan \& Ezebuihe, 2017; Aka, 2017; Alrasheedy \& Alaidarous, 2018). Another influential factor was the misuse of public and private offices in the form of corruption. In Indonesia, corruption is still considered apprehensive (Sasongko \& Huruta, 2018). The 
Corruption Eradication Commission (2019a) reported that corruption in Indonesia is dominated by bribery and the procurement of goods and services. Corruption increases government expenditure and reduces government revenues that will eventually reduce the economic growth and inhibit public capital accumulation (Mauro, 1996; Tanzi \& Davoodi, 1997; Tsoukis \& Alyousha, 2001; Pulok, 2010). In the private sector, corruption increases operating costs through illegal payments, costs to negotiate with corrupt officials, and risk of agreement cancellation due to litigation (Gupta, de Mello, \& Sharan, 2001; Al-Afeef \& Al-Qudah, 2015; Aka, 2017; Corruption Eradication Commission, 2019b).

\section{Conclusions}

Investment and saving are the most important financing sources in an economy. This study finds no short-run causal relationship between investment and saving in Indonesia from 1981 to 2018. However, in the long-run, saving has affected investment. Further, saving is highly related to investment. These findings indicate that the IS curve did not hold in the short-run but only held in the long-run.

Similarly, the VECM test suggests that the error correction value has a low significance level. The findings explain that Indonesia did not have a stable long-run relationship between investment and saving. Indeed, the ties fluctuated, which made the long-run relationship not constant. When the IS curve did not hold in the short-run, several factors with the short-run effects on saving had to be factors.

When saving increased, more loans were allocated for the consumption loans. Therefore, it could be understood that investment that should increase and the increased saving did not occur in the short-term. In the long-run, the increase in loans would ultimately encourage investment to produce consumption goods. Meanwhile, the increased investment would increase employment opportunities. However, with the wages to be still at the minimum level, GDP could not increase saving but slightly increased the consumption in a short span.
As an archipelago country, Indonesia inherently has a problem controlling the central and local government. Additionally, Indonesia also implements a decentralization policy that slows down the adoption of macro policies. The central government's policy implementation to local government needs more adjustment time to ensure the synergy and harmonization of policies. Future studies are suggested to use the Panel Structural Vector Autoregression model or Panel Autoregressive Distributed Lag to explain better the shocks that affect the IS in each region's short-run in Indonesia.

\section{References}

1. Abusomwan, S., \& Ezebuihe, E. (2017) Gross Domestic Savings and Gross Capital: What Matters to Their Formation in An Era of Economic Recession In Nigeria? Oradea Journal of Business and Economics. 2(2), pp. 45-55.

2. Aka, B. F. (2017) The Saving-Investment Relationships: A Markov Switching Causality Analysis of Cote D'Ivoire and Ghana. Applied Econometrics and International Development. 7(2), pp. 155162.

3. Al-Afeef, M. A., \& Al-Qudah, A. A. (2015). The Causal Relationship between Savings and Investment in Jordan (A prospective study for the period 1980-2013). Journal of Economics and Sustainable Development. 6(10), pp. 229-237.

4. Alrasheedy, A., \& Alaidarous, H. (2018) The Relationship between Saving and Investment: The Case of Saudi Arabia. SAMA Working Paper No. 17/9. Saudi Arabia. DOI:10.5539/ijef.v11n11p64

5. Banerjee, A., Dolado, J. J., \& Mestre, R. (1998. Error-correction mechanism tests for cointegration in a single-equation framework Journal of Time Series Analysis. 19(3), pp. 267-283. DOI: 10.1111/14679892.00091

6. Bank of Indonesia. (2019a) External Debt Statistics of Indonesia, Bank of Indonesia. Retrieved from https:// www. bi.go. id/en/iru/economic-data /external-debt /Pages/ SULNI-July -2019.aspx (Accessed: October 22, 2020).

7. Bank of Indonesia. (2019b) Survei Perbankan, Bank of Indonesia. Retrieved 
from https://www.bi. go.id/id/publikasi/ survei/perbankan/ (Accessed: October 21, 2020).

8. Bank of Indonesia. (2020) History of Bank Indonesia: Monetary Period from 1959$1966 . \quad$ Retrieved from https://www.bi.go.id/en/tentangbi/museum/sejarah-bi/ bi/ Documents/bab 292dd8e 834926a7d 7be04e 9dfe6c7Microsoft Word Historyof MonetaryPeriod 195919 66.pdf (Accessed: October 21, 2020).

9. Central Bureau of Statistics. (2015) Survei Khusus Tabungan dan Investasi Rumah Tangga, Central Bureau of Statistics. Retrieved from https://sirusa.bps. go.id/webadmin/pedoman/2015_3344_pe d_Pedoman Umum Pelaksanaan Lapangan SKTIR Tahun 2015.pdf (Accessed: October 21, 2020).

10. Central Bureau of Statistics. (2016) PDB Triwulanan Atas Dasar Harga Konstan 2010 Menurut Pengeluaran (Miliar Rupiah), 2010-2013, Central Bureau of Statistics. Retrieved from https://www.bps.go.id /dynamictable/2016/02/05/1128/-seri2010-pdb-triwulan an-atas-dasar-hargakonstan-2010-menurut- pengeluaranmiliar-rupiah-2010-2013.html (Accessed: October 22, 2020).

11. Central Bureau of Statistics. (2019) PDB Triwulanan Atas Dasar Harga Konstan 2010 Menurut Pengeluaran (Miliar Rupiah), 2014-2019, Central Bureau of Statistics. Retrieved from https://www. bps.go.id/dynamictable/2015/08/06/833 /-seri- 2010-pdb-triwulanan-atas- dasarharga-konstan-2010- menurutpengeluaran-miliar-rupiah -20142019.html (Accessed: October 22, 2020).

12. Corruption Eradication Commission. (2019a) Dampak Masif Korupsi Terhadap Ekonomi, Corruption Eradication Commission. Retrieved from https://aclc. kpk.go.id/materi/ bahaya-dan-dampakkorupsi/ infografis/dampak-korupsiterhadap -ekonomi (Accessed: October 22, 2020).

13. Corruption Eradication Commission. (2019b) Statistik Tindak Perkara Korupsi Berdasarkan Jenis Perkara, Corruption Eradication Commission. Retrieved from https://www.kpk.go.id/id/statistik /penindakan/tpk-berdasarkan-jenisperkara (Accessed: October 22, 2020).

14. Dolphin, T. (2012) Young people and saving: $A$ route to improved financial resilience. Retrieved from https://www.ippr .org/files/images/media /files/ publication/2012/11/young-peoplesavings_Nov2012_9849.pdf (Accessed: October 25, 2020).

15. Esso, L. J., \& Keho, Y. (2010) The SavingsInvestment Relationship: Cointegration and Causality Evidence from Uemoa Countries. International Journal of Economics and Finance. 2(1), pp.174-181. DOI: $10.5539 /$ ijef.v2n1p174

16. Gebeyehu, W. (2011) Causal Links among Saving, Investment and Growth and Determinants of Saving in Sub-Saharan Africa: evidence from Ethiopia. Ethiopian Journal of Economics. 19(2), pp.1-34.

17. Granger, C. W. J. (1969) Investigating Causal Relations by Econometric Models and Cross-spectral Methods. Econometrica. 37(3), pp. 424-438. DOI: 10.2307/1912791

18. Gupta, S., de Mello, L., \& Sharan, R. (2001) Corruption and military spending. European Journal of Political Economy. 17(4), pp.749-777. DOI: 10.1016/S01762680(01)00054-4

19. Hill, R. C., Griffiths, H. E., \& Lim, G. C. (2018) Principles of Econometrics (5th ed.). New Jersey: Wiley.

20. Hundie, S. K. (2014) Savings, investment and economic growth in Ethiopia: Evidence from ARDL approach to co-integration and TYDL Granger-causality tests. Journal of Economics and International Finance. 6(10), pp. 232-248. DOI: 10.5897/JEIF2014.0600

21. Irandoust, M. (2017) Saving and investment causality: implications for financial integration in transition countries of Eastern Europe. International Economics and Economic Policy. 16, pp. 1-20. DOI: 10.1007/s10368-017-0390-6

22. Itoe, B., \& Atangana, E. M. (2015) SavingsInvestment Relationship in Cameroon: Vector Auto Regressive Analysis. International Invention Journal of Arts and Social Sciences. 2(3), pp.33-43.

23. Jangili, R. (2011). Causal relationship between saving, investment and economic growth for India - what does the relation 
imply? Reserve Bank of India Occasional Papers. 32(1), pp.25-39.

24. Jappelli, T., \& Modigliani, F. (1998) The agesaving profile and the life-cycle hypothesis. CSEF Working Paper No. 9. Napoli. DOI: 10.7551/mitpress/1923.003.0008

25. Johnson, R. A., \& Wichern, D. W. (2007) Applied Multivariate Statististical Analysis (6th ed.). New Jersey: Pearson Prentice Hall. Available at:

26. Jošić, H., \& Jošić, M. (2012) Testing the validity of the Feldstein-Horioka puzzle for Croatia. Economic Research-Ekonomska Istrazivanja. 25(3), pp. 580-599. DOI: 10.1080/1331677X.2012.11517524

27. Kaya, H. (2010) Saving Investment Association in Turkey. Middle East Economic Association and Loyola University Chicago. 12, pp. 1-16.

28. Kira, A. R. (2013) The Factors Affecting Gross Domestic Product (GDP) in Developing Countries: The Case of Tanzania. European Journal of Business and Management. 5(4), pp.148-158.

29. Klemm, A. (2013) Growth Following Investment and Consumption-Driven Current Account Crises No. 13/217. Retrieved from https://www.imf. org/external/pubs/ft/wp/2013/wp13217 .pdf (Accessed: October 26, 2020).

30. Kumar, S., Webber, D. J., \& Fargher, S. (2012) Testing the validity of the FeldsteinHorioka puzzle for Australia. Applied Economics. 44(5), pp. 599-605. DOI: $10.1080 / 00036846.2010 .511993$

31. Mankiw, N. G. (2016) Macroeconomics (9th ed.). New York: Worth Publisher.

32. Mansoor, A., Sultana, B., \& Saeed, R. (2018) Analyzing the Savings-Investment Trend in a Panel of G-7 Countries. Asian Journal of Economics and Empirical Research 5(2), pp. 147-154. DOI: 10.20448/journal. 501.2018.52.147.154

33. Mauro, P. (1996) The Effects of Corruption on Growth, Investment, and Government Expenditure. IMF Working Paper No. 96/98. Retrieved from https://papers.ssrn.com/sol3/papers.cfm ?abstract_id=882994 (Accessed: October 22, 2020).

34. Mehrara, M., \& Musai, M. (2014) Investment and Saving Nexus in Asian Countries: Panel Cointegration and
Causality. International Letters of Social and Humanistic Sciences. 18, pp. 1-7.

35. Mensah, R. (2012) The Long-run Relationship between Savings and Investment in Transition Economies: Empirical Evidence from China. Lund University.

36. Ministry for Economic Affairs of Republic Indonesia. (2017) Perjalanan Ekonomi Indonesia 1945-2017. Retrieved from https://geologi.co. id/wp-content/uplo ads/2017/12 /Buklet- EkonomiIndonesia-18x24cm-1. pdf (Accessed: October 27, 2020).

37. Mngqibisa, V. (2014) Saving and Investment in South Africa: A Causality Study. Department of Economics at Rhodes University. Rhodes University. DOI: 10.1192/bjp.205.1.76a

38. Modigliani, F. (1986) Life cycle, individual thrift, and the wealth of nations. The American Economic Review. 76(3), pp.297313. DOI: $10.1126 /$ science.234.4777.704

39. Ngouhouo, I., \& Mouchili, E. (2014). Saving, Investment and Economic Growth in Cameroun: A Multivariate Approach. International Journal of Economics and Finance. 6(9), 244-252. DOI:10.5539/ijef.v6n9p244

40. Niu, H., Chu, X., \& Ma, Y. (2016). Study on the Fluctuation of Purchasing Power Parity. Open Journal of Business and Management. 4, $\quad$ pp. 67-78. DOI: 10.4236/ojbm.2016.4100

41. Ogbokor, C. A., \& Musilika, O. A. (2014). Investigating the relationship between Aggregate Savings and Investment in Namibia: A Causality Analysis. Research Journal of Finance and Accounting, 5(6), pp. 82-89.

42. Onafowara, O. A., Owoye, O., \& Huart, F. (2011) The Temporal Relationship between Saving and Investment: Evidence from Advanced EU Countries. International Journal of Business and Social Science. 2(2), pp. 1-12.

43. Organisation for Economic Cooperation and Development. (2011) New International Comparisons of GDP and Consumption Based on Purchasing Power Parities for the year 2011. Organisation for Economic Cooperation and Development. Retrieved from https://www.oecd.org 
/sdd/prices-ppp/ppps-2011- benchmark year.html (Accessed: October 22, 2020).

44. Park, D., \& Shin, K. (2009) Saving, Investment, and Current Account Surplus in Developing Asia. No. 158. Metro Manila. Retrieved from https://www.adb.org/sites/default/files/ publication/28249/economics-wp158.pdf (Accessed: October 22, 2020).

45. Pulok, M. H. (2010) The Impact of Corruption on Economic Development of Bangladesh: Evidence on the Basis of an Extended Solow Model. No. 39922. Munich. Retrieved from https://mpra.ub.unimuenchen.de/28755/1/MPRA_paper_287 55.pdf (Accessed: October 23, 2020).

46. Rahman, Z., \& Hossain, M. E. (2015) Testing Causality and Cointegration Between Saving and Investment in Bangladesh. Economics. 4(6), pp. 125-131. DOI: 10.11648/j.eco.20150406.15

47. Sakalya, V. S. (2012) Savings and Investment in India: The Feldstein Horioka Puzzle. Applied Econometrics and International Development. 12(2), pp.1-14.

48. Sasongko, G., \& Huruta, A. D. (2018) Monetary policy and the causality between inflation and money supply in Indonesia. Business: Theory and Practice. 19, pp. 80-87. DOI: 10.3846/btp.2018.09

49. Tanzi, V., \& Davoodi, H. R. (1997) Corruption, Public Investment, and Growth, IMF Working Paper. No. 9/139. DOI: 10.5089/9781451929515.001

50. Tehranchian, A. M., \& Behravesh, M. (2011) The relationship between savings and investment in Iran: Testing Feldstein's and Horioka's theory. African journal of business management. 5(4), pp.1408-1412. DOI: 10.5897/AJBM10.1303

51. Tsoukis, C., \& Alyousha, A. (2001) The Feldstein-Horioka Puzzle, SavingInvestment Causality and International Financial Market Integration. Journal of Economic Integration, 16(2), pp.262-277. DOI: $10.11130 /$ jei.2001.16.2.262

52. World Bank. (2019a) Current Account Balance (\% of GDP) - Indonesia, World Bank. Available at: https://data.worldbank.org/indicator/BN. CAB.XOKA.GD.ZS?locations =ID (Accessed: October 22, 2020).

53. World Bank. (2019b) Domestic Credit Provided by Financial Sector (\% of GDP) -
Indonesia, World Bank. Retrieved from https://data.worldbank.org/indicator/FS. AST.DOMS.GD.ZS?locations=ID (Accessed: October 22, 2020).

54. World Bank. (2019c) Households and NPISHs Final Consumption Expenditure, PPP (Constant 2011 International \$), World Bank. Retrieved from https://data.worldbank.org/indicator/NE. CON.PRVT.PP.KD?locations=ID (Accessed: October 22, 2020).

55. World Bank. (2019d) International Comparison Program (ICP), World Bank. Retrieved from https://www.worldbank. org/en/programs/icp (Accessed: October $25,2020)$.

56. World Bank. (2019e) Wage and Salaried Workers, Total (\% of Total Employment) (Modeled ILO estimate) - Indonesia, World Bank. Retrieved from https://data.worldbank.org/indicator/SL. EMP.WORK.ZS?locations=ID (Accessed: October 25, 2020).

57. Yadav, I. S., Goyari, P., \& Mishra, R. K. (2018) Saving, Investment and Growth in India: Evidence from Cointegration and Causality Tests. Economic Alternatives. 1, pp. 55-68.

58. Yamori, N. (1995). The relationship between domestic savings and investment: The Feldstein-Horioka test using Japanese regional data. Economics Letters. 48(3-4), pp. 361-366. DOI: 10.1016/01651765(94)00616-A 